\title{
Brevibacterium celere sp. nov., isolated from degraded thallus of a brown alga
}

Correspondence
Elena P. Ivanova
eivanova@swin.edu.au

The genus Brevibacterium was proposed by Breed (1953) for some Gram-positive, non-spore-forming, non-branching rods formerly classified as members of the genus 'Bacterium'. A number of species with diverse morphological, physiological and biochemical properties were subsequently included in the genus (Breed, 1957). The description of the genus was later emended and restricted only to the species that correspond to the type species Brevibacterium linens in terms of morphological and chemotaxonomic characteristics (Collins et al., 1980). Along with B. linens, the following Brevibacterium (sensu stricto) species are currently recognized within the genus:

The GenBank/EMBL/DDBJ accession number for the 16S rRNA gene sequence of Brevibacterium celere KMM $3637^{\top}$ is AY228463.

A consensus tree including ' $B$. sanguinis' and the fatty acid compositions of $B$. celere $\mathrm{sp}$. nov. strains are available as supplementary material in IJSEM Online.
Brevibacterium casei, Brevibacterium epidermidis (Collins et al., 1983), Brevibacterium iodinum (Collins et al., 1980), Brevibacterium mcbrellneri (McBride et al., 1993), Brevibacterium otitidis (Pascual et al., 1996), Brevibacterium avium (Pascual \& Collins, 1999), Brevibacterium paucivorans (Wauters et al., 2001) and Brevibacterium luteolum (Wauters et al., 2003; Euzéby \& Tindall, 2004). Brevibacteria are isolated from dairy milk products, encountered in humans as commensals or opportunistic pathogens, are found to be residents of poultry and also occur in marine and terrestrial environments, as reported by Collins (1992) and Jones \& Keddie (1986), and are available from public databases.

Here we describe two strains, KMM $3637^{\mathrm{T}}$ and KMM 6008, isolated from degraded thallus of the brown alga Fucus evanescens. Algae were collected (by scuba-diving) in midsummer (July 1999) at Kraternaya Bay, Kuril Islands, in the Pacific Ocean, during the 23rd scientific expedition of the 
$\mathrm{R} / \mathrm{V}$ Akademician Oparin. The set-up of the enrichment experiments and bacterial isolation were as described elsewhere (Ivanova et al., 2002), with the modification that a protein inhibitor of endo-(1,3)- $\beta$-D-glucanases (Yermakova et al., 2002) was added to the enrichment culture (E. P. Ivanova, unpublished). Cultures were maintained on marine agar (Difco) plates and medium B $[0 \cdot 2 \%(\mathrm{w} / \mathrm{v})$ Bacto peptone (Difco); $0 \cdot 2 \%(\mathrm{w} / \mathrm{v})$ casein hydrolysate (Merck); $0.2 \%$ (w/v) Bacto yeast extract (Difco); $0.1 \%(\mathrm{w} / \mathrm{v})$ glucose; $0.02 \%(\mathrm{w} / \mathrm{v}) \quad \mathrm{KH}_{2} \mathrm{PO}_{4}$; $0.005 \%(\mathrm{w} / \mathrm{v}) \quad \mathrm{MgSO}_{4} .7 \mathrm{H}_{2} \mathrm{O} ; 1.5 \%(\mathrm{w} / \mathrm{v})$ Bacto agar (Difco); $50 \%$ natural sea water; $50 \%$ distilled water at $\mathrm{pH} 7 \cdot 5-7 \cdot 8]$ and in marine broth supplemented with $30 \%$ $(\mathrm{v} / \mathrm{v})$ glycerol at $-80^{\circ} \mathrm{C}$. All isolates were streaked on agar plates from broth cultures every 6 months to ensure purity and viability.

Unless otherwise indicated, the phenotypic properties used for characterization of the two strains were tested by following established procedures (Smibert \& Krieg, 1994) and as described elsewhere (Ivanova et al., 1996). The cell morphology was determined on cultures grown for 12 , 24, 36 and $72 \mathrm{~h}$ on trypticase soy agar (Oxoid) and marine agar at $28^{\circ} \mathrm{C}$. The following physiological and biochemical properties were examined: oxidation/fermentation of glucose (Hugh \& Leifson, 1953), denitrification (Azegami et al., 1987), catalase activity, gelatin liquefaction, arginine dihydrolase, lysine decarboxylase and ornithine decarboxylase activity, indole and $\mathrm{H}_{2} \mathrm{~S}$ production and the ability to hydrolyse starch, Tween 80 and casein. Alginate (sodium salt) $(0 \cdot 1 \%, \mathrm{w} / \mathrm{v})$ hydrolysis was determined by assessing the development of clear zones around the colonies. The haemolytic activity of the strains studied was detected on blood agar comprising $40 \mathrm{~g}$ trypticase soy agar $\mathrm{l}^{-1}, 50 \mathrm{ml}$ sheep blood and $950 \mathrm{ml}$ water. Haemolytic activity on mouse erythrocytes and cytotoxicity on Ehrlich cells were tested on butanol extracts of the strains, as described earlier (Ivanova et al., 2001). Pyrazinamidase and acid production from 2,3-butylene glycol were detected as described by Wauters et al. (2001). Oxidative utilization of 95 carbon sources was tested by using Biolog GN Microplates (Rüger \& Krambeck, 1994). Growth at different temperatures, $\mathrm{NaCl}$ concentrations or $\mathrm{pH}$ values was measured using optical density at $660 \mathrm{~nm}$ after $24 \mathrm{~h}$ incubation in medium B. The incubation temperatures employed ranged from 5 to $45^{\circ} \mathrm{C}$. The $\mathrm{NaCl}$ concentrations used were in the range $0-15 \%(\mathrm{w} / \mathrm{v})$. The $\mathrm{pH}$ was adjusted within the range $4 \cdot 5-12 \cdot 0$ by using $\mathrm{HCl}$ and $\mathrm{NaOH}$. Susceptibility to antibiotics was tested by using the routine diffusion plate method, employing medium B agar and discs impregnated with the antibiotics listed in the species description. The results of examination of the morphological and physiological properties are given in Table 1 and in the species description.

Table 1. Differential phenotypic characteristics of $B$. celere sp. nov. and other species of the genus

Taxa: 1, B. celere sp. nov.; 2, B. avium; 3, B. mcbrellneri; 4, B. casei; 5, B. epidermidis; 6, B. otitidis; 7, B. iodinum; 8, B. linens; 9, B. paucivorans; 10 , B. luteolum. Symbols: + , positive; - , negative, $\mathrm{V}(+)$, variable, mostly positive; $\mathrm{W}$, weak reaction; ND, no data available. Data are from this study, Jones \& Keddie (1986), Pascual \& Collins (1999) and Wauters et al. (2001, 2003).

\begin{tabular}{|c|c|c|c|c|c|c|c|c|c|c|}
\hline Characteristic & 1 & 2 & 3 & 4 & 5 & 6 & 7 & 8 & 9 & 10 \\
\hline Colonies & $\begin{array}{l}\text { Whitish } \\
\text { yellow, } \\
\text { smooth }\end{array}$ & $\begin{array}{l}\text { Whitish- } \\
\text { grey, } \\
\text { smooth }\end{array}$ & $\begin{array}{c}\text { Greyish, } \\
\text { dry }\end{array}$ & $\begin{array}{l}\text { Whitish- } \\
\text { grey, } \\
\text { smooth }\end{array}$ & $\begin{array}{l}\text { Whitish- } \\
\text { yellow, } \\
\text { smooth }\end{array}$ & $\begin{array}{l}\text { Yellowish, } \\
\text { smooth }\end{array}$ & $\begin{array}{l}\text { Whitish- } \\
\text { grey, } \\
\text { smooth }\end{array}$ & $\begin{array}{l}\text { Yellow- } \\
\text { orange } \\
\text { smooth }\end{array}$ & $\begin{array}{l}\text { Greyish, } \\
\text { smooth } \\
\text { or sticky }\end{array}$ & $\begin{array}{l}\text { Yellowish, } \\
\text { smooth }\end{array}$ \\
\hline \multicolumn{11}{|l|}{ Growth at: } \\
\hline $12^{\circ} \mathrm{C}$ & + & - & - & - & - & - & - & - & - & - \\
\hline $20{ }^{\circ} \mathrm{C}$ & + & ND & - & + & + & - & + & + & - & + \\
\hline $37^{\circ} \mathrm{C}$ & + & + & + & + & + & + & + & $\mathrm{W}$ & + & + \\
\hline Oxidase & + & + & ND & - & - & ND & + & $\mathrm{W}$ & ND & ND \\
\hline $\mathrm{NaCl}$ tolerance $(\%, \mathrm{w} / \mathrm{v})$ & 15 & ND & ND & 15 & 15 & ND & ND & 15 & ND & 10 \\
\hline \multicolumn{11}{|l|}{ Hydrolysis of: } \\
\hline Casein & - & + & ND & + & + & + & $\mathrm{W}$ & + & - & + \\
\hline Gelatin & + & + & ND & + & + & + & + & + & $\mathrm{W}$ & + \\
\hline Nitrate reduction & - & + & - & $\mathrm{V}(+)$ & $\mathrm{V}(+)$ & - & + & + & - & - \\
\hline $\begin{array}{l}\text { Acid production from } \\
\text { 2,3-butylene glycol }\end{array}$ & - & ND & + & - & - & - & - & - & - & - \\
\hline \multicolumn{11}{|l|}{ Utilization of: } \\
\hline D-Arabinose & - & - & - & + & - & - & - & - & - & - \\
\hline Mannitol & - & + & - & - & + & - & - & - & - & - \\
\hline Gluconate & - & - & - & + & + & - & - & - & - & - \\
\hline Pyrazinaminidase & - & ND & - & + & + & + & + & + & - & + \\
\hline$\alpha$-Glucosidase & + & - & - & $\mathrm{v}(+)$ & - & - & - & - & - & - \\
\hline
\end{tabular}


The 16S rRNA gene was amplified and sequenced by MIDI Labs. Briefly, the primers used for the amplification corresponded to Escherichia coli positions 5 and 1540. Amplification products were purified using Microcon 100 (Millipore) molecular mass cut-off membranes and were checked for quality and quantity on an agarose gel. Cycle sequencing of the 16S rRNA gene amplification products was carried out using AmpliTaq ES DNA polymerase (PE Biosystems) and rhodamine dye terminators (PE Biosystems). The samples were electrophoresed on an ABI Prism 377 DNA sequencer (PE Biosystems).

Phylogenetic analyses were done as reported previously (Ivanova et al., 2004) and are explained in detail at http://bioinfo.unice.fr (Publications section, document: Phylogeny_How). The domains used to construct the final phylogenetic trees were positions 75-996 and 10131413 of the strain KMM $3637^{\mathrm{T}}$ sequence, excluding domains for which alignments were insecure. Phylogenetic trees were constructed according to three methods, BIONJ (Gascuel, 1997), maximum likelihood and maximum parsimony, as described by Ivanova et al. (2004). Fig. 1 shows a consensus tree for neighbour-joining (bootstrap analysis, 1000 replications), maximum-likelihood and maximum-parsimony analyses. The $16 \mathrm{~S}$ rRNA gene sequence analyses revealed that strain KMM $3637^{\mathrm{T}}$ is a member of the genus Brevibacterium, $B$. casei being the closest phylogenetic neighbour (with a similarity value of $97 \%$ ). However, because eight positions of 16S RNA gene sequence of KMM $3637^{\mathrm{T}}$ were not identified, this percentage may be greater (up to $98 \%$ ). According to published data, bacteria that differ by more than $2.5 \%$ at the $16 \mathrm{~S}$ rRNA gene sequence level are unlikely to exhibit more than $60-70 \%$ similarity at the genomic

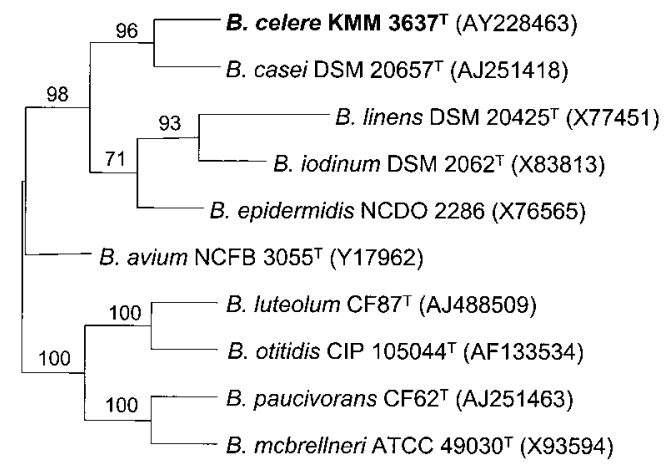

Fig. 1. Phylogenetic position of $B$. celere sp. nov. $\mathrm{KMM} 3637^{\top}$ according to $16 \mathrm{~S}$ rRNA gene sequence analysis. The topology shown was obtained using the BIONJ algorithm (Gascuel, 1997) and 1000 bootstrap replications with Kimura's two-parameter correction (Kimura, 1980) for the distances. Bootstrap percentages are indicated only for branches that were also retrieved by maximum parsimony and maximum likelihood $(P<0.01)$; these branches should be considered as the only robust clusters identified by this analysis.
DNA level (Stackebrandt \& Goebel, 1994; Rosselló-Mora \& Amann, 2001): we were therefore at the threshold level for the definition of a novel species. Additional DNA-DNA hybridization experiments were performed to resolve this issue (see below). It should also be stated that, during the revision of the manuscript, a new sequence, which was the closest to that of strain $\mathrm{KMM} 3637^{\mathrm{T}}$, appeared in the public database ('Brevibacterium sanguinis', accession no. AJ564859; see the Supplementary Figure in IJSEM Online). However, we did not take it into account since the species does not yet have a validly published name.

The DNA was isolated according to the method of Marmur (1961). The G +C content of the DNA (61-62 mol\%) was determined by using the thermal denaturation method of Marmur \& Doty (1962). DNA-DNA hybridization was performed spectrophotometrically and initial renaturation rates were recorded as described by De Ley et al. (1970). The level of DNA relatedness between the two strains from the alga was $98 \%$. DNA hybridization analysis also indicated that there was $45 \%$ hybridization between strain KMM $3637^{\mathrm{T}}$ and B. casei DSM $20657^{\mathrm{T}}$. These data clearly indicate that the novel strains belong to a separate genomic species (Wayne et al., 1987; Stackebrandt \& Goebel, 1994).

The amino acid composition of the peptidoglycan was determined using TLC on cellulose (modified method of Hasegawa et al., 1983; Rhuland et al., 1955). The peptidoglycan contained meso-diaminopimelic acid, which is characteristic of the genus Brevibacterium [peptidoglycan type A1 $\gamma$ ( $m$-Dpm direct, type A31); DSMZ, 2001].

Analysis of fatty acid methyl ethers was performed by GLC as described by Svetashev et al. (1995). The most relevant cellular fatty acids were saturated, anteiso- and iso-methylbranched acids, namely 12-methyltetradecanoic (15:0ai) and 14-methylhexadecanoic (17:0ai) fatty acids, which comprised up to $80 \%$ of the total, while $15: 0 \mathrm{i}$ and $16: 0 \mathrm{i}$ were present as minor components (Supplementary Table in IJSEM Online).

Phenotypically, the two strains differed from other species of the genus Brevibacterium by the characteristics presented in Table 1. The strains are delineated from the species known to be tolerant of up to $15 \%(\mathrm{w} / \mathrm{v}) \mathrm{NaCl}$ (B. linens, B. casei and B. epidermidis) by colony colour, the presence of oxidase activity, the lack of nitrate reduction, the inability to hydrolyse casein and the utilization of different carbon sources. The novel organisms exhibited the ability to hydrolyse some algal polysaccharides (laminaran, alginate) and did not exhibit haemolytic, cytotoxic or antibacterial activities. The growth temperature range, the salt tolerance and the inability to reduce nitrate or hydrolyse casein differentiate the novel organisms from other Brevibacterium species. Consequently, we propose that the two strains isolated from brown algae be classified as a novel species, for which the name Brevibacterium celere sp. nov. is proposed. 


\section{Description of Brevibacterium celere sp. nov.}

Brevibacterium celere (ce'le.re. L. neut. adj. celere rapid, indicating the rapid growth on nutrient media).

Cells are Gram-positive, non-motile, non-acid-fast, nonspore-forming rods with coryneform morphology. Colonies are circular, convex, with entire margins, whitish yellow in colour and of a smooth and butyrous consistency. Salttolerant. Growth occurs at $0-15 \%(w / v) ~ N a C l$. Growth occurs at $12-42^{\circ} \mathrm{C}$. No growth is detected at $4{ }^{\circ} \mathrm{C}$ or at $45^{\circ} \mathrm{C}$. Alkali-tolerant. Growth occurs at $\mathrm{pH} 5-10$, with optimum growth at $\mathrm{pH} 8 \cdot 5-9 \cdot 0$. The organism is catalaseand oxidase-positive and exhibits aerobic metabolism. Gelatin, laminaran and alginate are hydrolysed, but casein and starch are not. Nitrate is not reduced to nitrite. Tests for urease and pyrazinamidase are negative. No acid is formed from glucose, maltose, lactose, sucrose, galactose, xylose or sorbose. According to the Biolog results, the following substrates are utilized: dextrin, Tween 40, Tween $80, \mathrm{~N}$-acetyl-D-galactosamine, $\mathrm{N}$-acetyl-D-glucosamine, Lfucose, $\alpha$-D-glucose, maltose, sucrose, D-trehalose, turanose, methylpyruvate, monomethyl succinate, acetic acid, cisaconitic acid, citric acid, formic acid, D-gluconic acid, $\alpha$-hydroxybutyric acid, $\beta$-hydroxybutyric acid, $\gamma$-hydroxybutyric acid, $p$-hydroxyphenylacetic acid, $\alpha$-ketobutyric acid, DL-lactic acid, propionic acid, quinic acid, sebacic acid, succinic acid, bromosuccinic acid, alaninamide, Dalanine, L-alanine, L-alanyl glycine, L-asparagine, L-aspartic acid, L-glutamic acid, glycyl L-glutamic acid, L-histidine, hydroxyproline, L-leucine, L-ornithine, L-phenylalanine, L-proline, L-pyroglutamic acid, L-serine, DL-carnitine, $\gamma$-aminobutyric acid, urocanic acid, phenylethylamine, putrescine and glycerol. In addition, strain KMM 3581 utilizes D-arabitol and i-erythritol. Susceptible to carbenicillin $(10 \mu \mathrm{g})$ and oleandomycin $(30 \mu \mathrm{g})$. Not susceptible to ampicillin $(10 \mu \mathrm{g})$, lincomycin $(15 \mu \mathrm{g})$, kanamycin $(30 \mu \mathrm{g})$, benzylpenicillin $(10 \mu \mathrm{g})$, neomycin $(30 \mu \mathrm{g})$, streptomycin $(30 \mu \mathrm{g})$, gentamicin $(10 \mu \mathrm{g})$ or polymyxin B $(25 \mu \mathrm{g})$. The predominant cellular fatty acids are odd-numbered, i.e. 15:0ai and 17:0ai. The peptidoglycan contains mesodiaminopimelic acid (peptidoglycan type $\mathrm{Al} \gamma$ ). The $\mathrm{G}+\mathrm{C}$ content of the DNA is $61 \cdot 4 \mathrm{~mol} \%$.

The type strain is KMM $3637^{\mathrm{T}}\left(=\mathrm{DSM} 15453^{\mathrm{T}}=\right.$ ATCC BAA $-809^{\mathrm{T}}$ ), isolated from the brown alga Fucus evanescens.

\section{Note added in proof}

After this paper had been accepted for publication, four more novel species of Brevibacterium were reported: Brevibacterium picturae (Heyrman et al., 2004), 'Brevibacterium antiquum', 'Brevibacterium aurantiacum' and 'Brevibacterium permense' (Gavrish et al., 2004).

\section{Acknowledgements}

The authors are thankful to Dr P. Schumann for determination of the amino acid composition of the peptidoglycan. This study was supported by funds from the Russian Foundation for Basic Research (grant 02-04-49517), the Ministry for Science, Industry and Technologies of the Russian Federation (grant 03-19) and the Australian Research Council. This work was also supported by funds from the European Commission for the AQUA-CHIP project (QLK4-200000764). The authors are solely responsible for the content of this publication. It does not represent the opinion of the European Commission. The European Commission is not responsible for any use that might be made of data appearing herein.

\section{References}

Azegami, K., Nishiyama, K., Watanabe, Y., Kadota, I., Ohuchi, A. \& Fukazawa, C. (1987). Pseudomonas plantarii sp. nov., the causal agent of rice seeding blight. Int J Syst Bacteriol 37, 144-152.

Breed, R. S. (1953). The families developed from Bacteriaceae Cohn with a description of the family Brevibacteriaceae. Rias Commun VI Int Cong Microbiol Roma 1, 10-15.

Breed, R. S. (1957). Family IX. Brevibacteriaceae Breed 1953. In Bergey's Manual of Determinative Bacteriology, 7th edn, pp. 490-503. Edited by R. S. Breed, E. G. D. Murray \& N. R. Smith. Baltimore: Williams \& Wilkins.

Collins, M. D. (1992). The genus Brevibacterium. In The Prokaryotes, 2nd edn, vol. 2, pp. 1351-1354. Edited by A. Balows, H. G. Trüper, M. Dworkin, W. Harder \& K.-H. Schleifer. New York: Springer.

Collins, M. D., Jones, D., Keddie, R. M. \& Sneath, P. H. A. (1980). Reclassification of Chromobacterium iodinum (Davis) in a redefined genus Brevibacterium (Breed) as Brevibacterium iodinum nom. rev.; comb. nov. J Gen Microbiol 120, 1-10.

Collins, M. D., Farrow, J. A. E., Goodfellow, M. \& Minnikin, D. E. (1983). Brevibacterium casei sp. nov. and Brevibacterium epidermidis sp. nov. Syst Appl Microbiol 4, 388-395.

De Ley, J., Cattoir, H. \& Reynaerts, A. (1970). The quantitative measurement of DNA hybridization from renaturation rates. Eur $J$ Biochem 12, 133-142.

DSMZ (2001). Catalogue of Strains, 7th edn. Braunschweig: Deutsche Sammlung von Mikroorganismen und Zellkulturen. http://www. dsmz.de/species/murein.htm

Euzéby, J. P. \& Tindall, B. J. (2004). Status of strains that contravene Rules 27(3) and 30 of the Bacteriological Code. Request for an Opinion. Int J Syst Evol Microbiol 54, 293-301.

Gascuel, O. (1997). BIONJ: an improved version of the NJ algorithm based on a simple model of sequence data. Mol Biol Evol 14, 685-695.

Gavrish, E. Yu., Krauzova, V. I., Potekhina, N. V., Karasev, S. G., Plotnikova, E. G., Altyntseva, O. V., Korosteleva, L. A. \& Evtushenko, L. I. (2004). Three new species of brevibacteria, Brevibacterium antiquum sp. nov., Brevibacterium aurantiacum sp. nov., and Brevibacterium permense sp. nov. Microbiology (English translation of Mikrobiologiya) 73, 176-183.

Hasegawa, T., Takizawa, M. \& Tanida, S. (1983). A rapid analysis for chemical grouping of aerobic actinomycetes. J Gen Appl Microbiol 29, 319-322.

Heyrman, J., Verbeeren, J., Schumann, P., Devos, J., Swings, J. \& De Vos, P. (2004). Brevibacterium picturae sp. nov., isolated from a damaged mural painting at the Saint-Catherine chapel (Castle Herberstein, Austria). Int J Syst Evol Microbiol 54, 1537-1541.

Hugh, R. \& Leifson, E. (1953). The taxonomic significance of fermentative versus oxidative metabolism of carbohydrates by various Gram-negative bacteria. J Bacteriol 66, 24-26.

Ivanova, E. P., Kiprianova, E. A., Mikhailov, V. V., Levanova, G. F., Garagulya, A. D., Gorshkova, N. M., Yumoto, N. \& Yoshikawa, S. 
(1996). Characterization and identification of marine Alteromonas nigrifaciens strains and emendation of the description. Int J Syst Bacteriol 46, 223-228.

Ivanova, E. P., Sawabe, T., Gorshkova, N. M., Svetashev, V. I., Mikhailov, V. V., Nicolau, D. V. \& Christen, R. (2001). Shewanella japonica sp. nov. Int J Syst Evol Microbiol 51, 1027-1033.

Ivanova, E. P., Bakunina, I. Y., Sawabe, T., Hayashi, K., Alexeeva, Y. V., Zhukova, N. V., Nicolau, D. V., Zvaygintseva, T. N. \& Mikhailov, V. V. (2002). Two species of culturable bacteria associated with degradation of brown algae Fucus evanescens. Microb Ecol 43, 242-249.

Ivanova, E. P., Gorshkova, N. M., Sawabe, T. \& 8 other authors (2004). Sulfitobacter delicatus sp. nov. and Sulfitobacter dubius sp. nov., respectively from a starfish (Stellaster equestris) and sea grass (Zostera marina). Int J Syst Evol Microbiol 54, 475-480.

Jones, D. \& Keddie, R. M. (1986). Genus Brevibacterium Breed 1953, $13^{\mathrm{AL}}$ emend. Collins et al. 1980, 6. In Bergey's Manual of Systematic Bacteriology, vol. 2, pp. 1301-1313. Edited by P. H. A. Sneath, N. A. Mair, M. E. Sharpe \& J. G. Holt. Baltimore: Williams \& Wilkins.

Marmur, J. (1961). A procedure for the isolation of deoxyribonucleic acid from microorganisms. J Mol Biol 3, 208-218.

Marmur, J. \& Doty, P. (1962). Determination of the base composition of deoxyribonucleic acid from its thermal denaturation temperature. J Mol Biol 5, 109-118.

McBride, M. E., Ellner, K. M., Black, H. S., Clarridge, J. E. \& Wolf, J. E. (1993). A new Brevibacterium sp. isolated from infected genital hair of patients with white piedra. J Med Microbiol 39, 225-261.

Pascual, C. \& Collins, M. D. (1999). Brevibacterium avium sp. nov., isolated from poultry. Int J Syst Bacteriol 49, 1527-1530.

Pascual, C., Collins, M. D., Funke, G. \& Pitcher, D. G. (1996). Phenotypic and genotypic characterization of two Brevibacterium strains from the human ear: description of Brevibacterium otitidis sp. nov. Med Microbiol Lett 5, 113-123.
Rhuland, L. E., Work, E., Denman, R. F. \& Hoare, D. S. (1955). The behaviour of the isomers of $\alpha, \varepsilon$-diaminopimelic acid on paper chromatograms. J Am Chem Soc 77, 4844-4846.

Rosselló-Mora, R. \& Amann, R. (2001). The species concept for prokaryotes. FEMS Microbiol Rev 25, 39-67.

Rüger, H.-J. \& Krambeck, H.-J. (1994). Evaluation of the BIOLOG substrate metabolism system for classification of marine bacteria. Syst Appl Microbiol 17, 281-288.

Smibert, R. M. \& Krieg, N. R. (1994). Phenotypic characterization. In Methods for General and Molecular Bacteriology, pp. 607-654. Edited by P. Gerhardt, R. G. E. Murray, W. A. Wood \& N. R. Krieg. Washington, DC: American Society for Microbiology.

Stackebrandt, E. \& Goebel, B. M. (1994). Taxonomic note: a place for DNA-DNA reassociation and $16 \mathrm{~S}$ rRNA sequence analysis in the present species definition. Int J Syst Bacteriol 44, 846-849.

Svetashev, V. I., Vysotskii, M. V., Ivanova, E. P. \& Mikhailov, V. V. (1995). Cellular fatty acids of Alteromonas species. Syst Appl Microbiol 18, 37-43.

Wauters, G., Charlier, J., Janssens, M. \& Delmée, M. (2001). Brevibacterium paucivorans sp. nov., from human clinical specimens. Int J Syst Evol Microbiol 51, 1703-1707.

Wauters, G., Avesani, V., Laffineur, K., Charlier, J., Janssens, M., Van Bosterhaut, B. \& Delmée, M. (2003). Brevibacterium lutescens sp. nov., from human and environmental samples. Int J Syst Evol Microbiol 53, 1321-1325.

Wayne, L. G., Brenner, D. J., Colwell, R. R. \& 9 other authors (1987). International Committee on Systematic Bacteriology. Report of the ad hoc committee on reconciliation of approaches to bacterial systematics. Int J Syst Bacteriol 37, 463-464.

Yermakova, S. P., Sova, V. V. \& Zvyagintseva, T. N. (2002). Brown seaweed protein as an inhibitor of marine mollusk endo-( $1 \rightarrow 3)$ beta-D-glucanases. Carbohydr Res 337, 229-237. 